\title{
The determination and role of peroxyacetil nitrate in photochemical processes in atmosphere
}

\author{
Karim Movassaghi ${ }^{1 *}$, Mario Vincenzo Russo ${ }^{2}$, Pasquale Avino ${ }^{3}$ \\ From CMA4CH 2010: Multivariate Analysis and Chemometry to Cultural Heritage and Environment \\ Taormina, Italy. 26-29 September 2010
}

\begin{abstract}
Peroxyacetilnitrates (PAN) is the most characteristic photoxidant of a range of secondary pollutants formed by the photochemical reaction of hydrocarbons with nitrogen oxides in the atmosphere: it is phytotoxic and shows an increasing role in human health effects due to ambient air exposure, especially in presence of high ozone concentrations. Because of the similarity of the conditions required for their photochemical production PAN is observed in conjunction with elevated ozone concentrations. PAN has very low natural background concentrations so it is the very specific indicator of anthropogenic photochemical air pollution. In this paper we report PAN concentrations determined in Rome urban area during winter- and summer-period. PAN measurements were carried out by means of a gas-chromatograph equipped with an Electron Capture Detector (ECD) detector. For identifying the acute episodes of atmospheric photochemical pollutants the relationship between PAN and the variable $\mathrm{O}_{x}\left(=\mathrm{NO}_{2}+\mathrm{O}_{3}\right)$ which describes the oxidation process evolution is investigated. The role of Volatile Organic Compounds and PAN in the ozone formation is investigated as well the issue of taking in account the autovehicular emissions for checking the $\mathrm{NO}_{x}$ fraction in fuel.
\end{abstract}

\section{Background}

Peroxyacetilnitrate $\left(\mathrm{PAN}, \mathrm{CH}_{3} \mathrm{C}(\mathrm{O}) \mathrm{OONO}_{2}\right)$ is the principal member of a family of nitrogenous compounds produced by action of sunlight on $\mathrm{NO}_{\mathrm{x}}$ and reactive hydrocarbons [1]. PAN has been known to be a phytotoxicant [2,3] and lachrymator [3,4]. There has also been considerations with regard to the role of PAN in the human health effects due to the exposure in ambient air, especially in the presence of high levels of ozone [5,6]. PAN is a suggested agent of skin cancer [7] in photochemically active areas and a possible bacterial mutagen $[8,9]$.

From an atmospheric chemistry point of view, PAN and $\mathrm{O}_{3}$ are the two most important components of photochemical smog, a very complex phenomena. Because of quite similar conditions required for their photochemical production, PAN is observed in conjunction with elevated

\footnotetext{
* Correspondence: movassaghi2000@yahoo.it

'Department of Chemistry, University of Isfahan, Isfahan, 81744, Iran Full list of author information is available at the end of the article
}

ozone concentrations but there are differences in the characteristics of these two compounds. Basically, photochemical production of $\mathrm{PAN}$ and $\mathrm{O}_{3}$ are very closely linked as both initiated by the reaction of hydrocarbons with the hydroxyl radical $(\mathrm{OH})$ and in presence of nitrogen oxides.

Although not well defined, the natural background concentration level of PAN is very low [3] so it is considered very specific indicator of anthropogenic photochemical air pollution; on the contrary ozone has relevant sources in stratosphere [10-12] where its level is high. It should be underlined that very few data are present in literature regarding of PAN levels in the atmosphere and so it is very hard to establish guideline values in air quality evaluation. Further, at low temperatures the PAN can represent an important reservoir for atmospheric odd nitrogen because the $\mathrm{NO}_{2}$ equilibrium (and the relative peroxyacetil radicals) depends strictly on the temperature [13]. Consequently, also the PAN lifetime in atmosphere strongly depends on the ambient temperature. This enables PAN to persist for a longer time at low temperature. Furthermore, PAN is 
slowly removed from the atmosphere through dry deposition; on the contrary, the ozone is rapidly removed and the dry deposition represents an effective destruction mechanism [14]. Therefore, episodes of long-range transport of PAN are likely to occur [15] and it is generally considered that PAN might constitute the largest fraction of the natural $\mathrm{NO}_{\mathrm{x}}$ reservoir [14]: this is confirmed by recent observations of high $\mathrm{PAN} / \mathrm{NO}_{\mathrm{x}}$ ratios in the cool middle free troposphere [16].

Precursors of PAN in polluted areas are specific nonmethane hydrocarbons (NMHCs) (particularly, propene, 1-butene, 2-butene, 2-pentene, etc.), aldehydes (formaldehyde, acetaldehyde) and $\mathrm{NO}_{2}$. Expecially in air masses polluted by anthropogenic emissions (i.e., autovehicular traffic and/or industrial emission), the NMHC abundance causes a rising of PAN mixing ratios sometime up to several ppbv [17].

In conjunction with the anthropogenic precursors, natural Volatile Organic Compounds (VOCs) such as isoprene [18] are relevant but of minor importance in urban and near urban atmospheres, where the PAN is the very specific indicator of anthropogenic photochemical air pollution [19-21].

For identifying the occurrence of a strong photochemical smog episode in the atmosphere, the PAN, $\mathrm{O}_{3}, \mathrm{NO}_{2}$ and $\mathrm{HCHO}$ concentrations are measured and the variable $\mathrm{O}_{\mathrm{x}}$ (sum of $\mathrm{O}_{3}$ and $\mathrm{NO}_{2}$ ) has been involved (Figure 1).

The present paper deals with the determination of PAN concentration in the urban area of Rome carried out in the period May 2007-April 2008. The meteorological conditions that may determine elevated PAN concentrations are here discussed and the relationships between measured concentrations of PAN, $\mathrm{O}_{3}, \mathrm{NO}_{2}$ and $\mathrm{HCHO}$ in this environment also described. A very important task of this research regards to set up the developing of an analytical procedure: indeed, the determination by a gas-chromatography technique (GC-ECD) does not require any sample enrichment. By means of this methodology the temporal evolution of these compounds can be followed and useful information on the photochemical pollution phenomena are derived and shown. Finally, it should be noted the difficulty to find out certified standard reference materials of PAN, Peroxymethylnitrate (PMN), Peroxypropionylnitrate (PPN) and $\mathrm{CH}_{3} \mathrm{ONO}_{2}$ for calibrating the instrumentations.

The reliability and accuracy of the analytical method have been verified through monitoring campaigns during photochemical smog episodes. Simultaneously, a large data-base on smog precursors (NO, reactive $\mathrm{NMHCs}$ ) and the relative products (ozone, PAN, aldehydes) in Rome urban area was collected.

\section{Results and discussion}

The monthly average PAN concentrations measured during the entire campaign are reported in Table 1 . The
PAN concentrations reached a maximum of $30.3 \mathrm{ppbv}$ in summertime (average daily level of $5.7 \mathrm{ppbv}$ ) and a maximum of $7.3 \mathrm{ppbv}$ in wintertime (average daily level of $2.1 \mathrm{ppbv})$.

In Figures 2 and 3 typical daily trends of PAN determined inside a green park, Villa Ada, in downtown Rome during summer and winter periods, respectively, are reported.

First of all, a clear difference about the amount is shown. During the summer period, the solar irradiation is strong and consequently the PAN production reaches very notable levels (up to $30 \mathrm{ppbv}$ ) compared with low levels in wintertime (maximum 5 ppbv). The really interesting consideration is that photochemical smog episodes occur also during cold period when the solar irradiation is low; meantime the VOC emissions are very significant as consequence of autovehicular traffic and domestic heating, characteristics of a great urban area such as Rome. Even if these episodes are limited and PAN does not reach high values, the occurring of this phenomena is important to understand the dynamics of the atmospheric pollution in the considered area and how the air quality is affected.

In Table 2 the average and max levels (expressed as ppbv) and the relative contributions (\%) to the total amount are reported for each hydrocarbons $\mathrm{C}_{2}-\mathrm{C}_{9}$ determined in downtown Rome during the cold period.

The total composition (79.2 ppbv) is very complex and almost all the hydrocarbons in the range $\mathrm{C}_{2}-\mathrm{C}_{9}$ are present: in particular, alkanes $44.3 \%$, alkenes $36.5 \%$ and aromatic $19.2 \%$. Another interesting consideration is the high content of ethane $(23.6 \%)$ and ethene $(70.4 \%)$ to alkane and alkene fractions, respectively. Considering the origin of these two species [22,23], the values are ascribed to the strong diesel-vehicle density in downtown Rome.

As it can be seen in Figures 2 and 3, the PAN behavior is almost regular depending strictly on both the meteorological conditions and the ozone and $\mathrm{HCHO}$ levels in atmosphere, overall the VOC such as described above.

In fact, in presence of high concentration levels of VOCs, radicals $\mathrm{RO}_{2}$ and $\mathrm{HO}_{2}$ are formed according to the following reactions:

$$
\begin{aligned}
& \text { VOCs }+\mathrm{OH}=\mathrm{RO}+\mathrm{H}_{2} \mathrm{O} \\
& \mathrm{HCHO}+\mathrm{hv}=\mathrm{H} \cdot+\mathrm{HCO} \\
& \mathrm{H}+\mathrm{O}_{2}+\mathrm{M}=\mathrm{HO}_{2} \cdot \mathrm{M} \\
& \mathrm{HCO}+\mathrm{O}_{2}=\mathrm{CO}+\mathrm{H}_{2} \mathrm{O}
\end{aligned}
$$




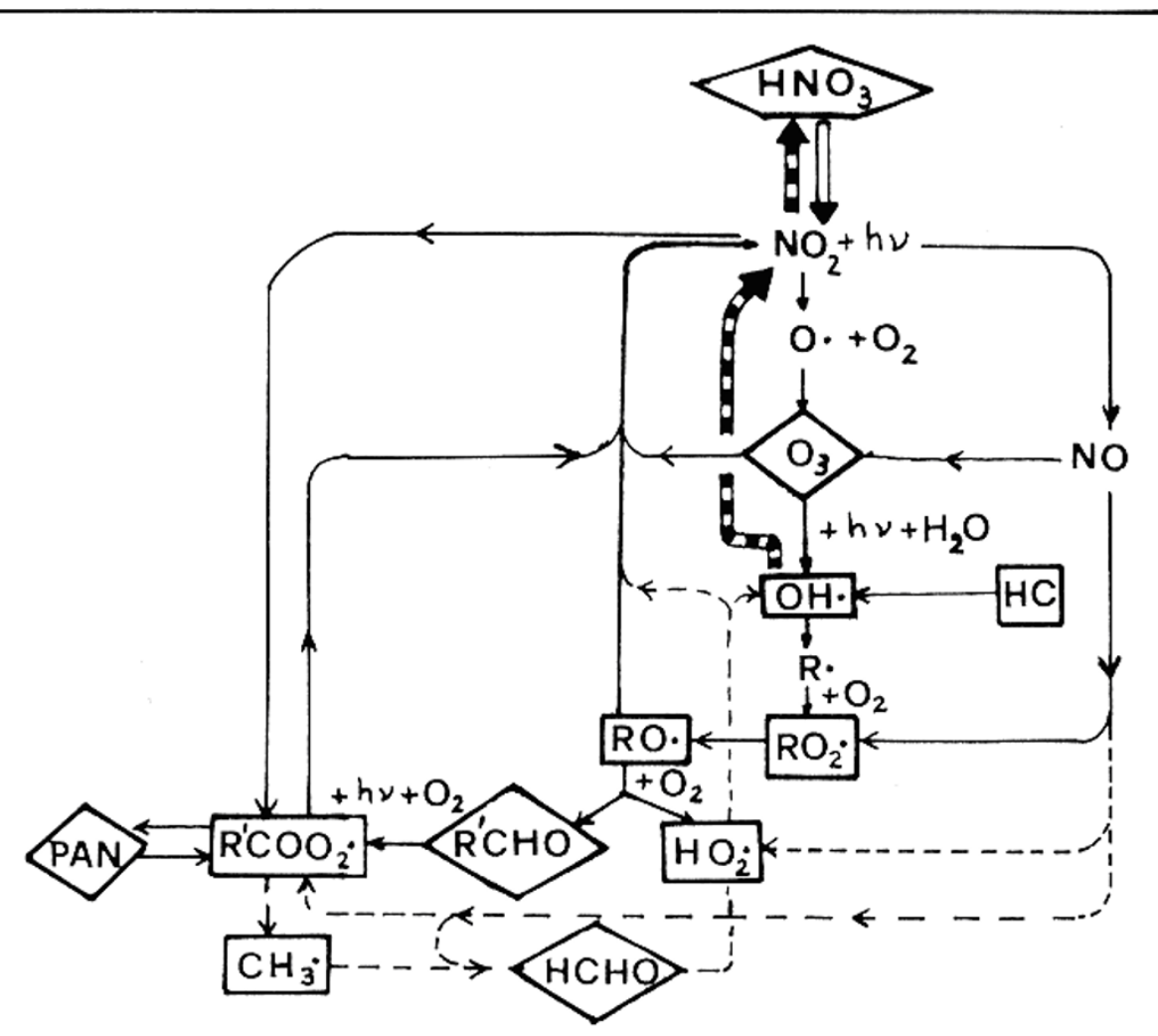

Figure 1 Master scheme of photochemical reactions occurring in atmosphere.

The radicals $\mathrm{RO}_{2}$ and $\mathrm{HO}_{2}$ react with $\mathrm{NO}$ giving $\mathrm{NO}_{2}$ :

$$
\begin{aligned}
& \mathrm{RO}_{2} \cdot \mathrm{NO}=\mathrm{NO}_{2}+\mathrm{RO} . \\
& \mathrm{H}_{2} \mathrm{O}+\mathrm{NO}=\mathrm{NO}_{2}+\mathrm{OH} .
\end{aligned}
$$

These last two reactions cause an increasing of the ratio $\mathrm{NO}_{2} / \mathrm{NO}$ and a relative ozone accumulation. At high $\mathrm{NO}_{\mathrm{x}}$ concentrations such as those recorded in urban areas, the radicals $\mathrm{RO}_{2}$ and $\mathrm{HO}_{2}$ can be removed by other reactions giving formation of more stable compounds:

$$
\mathrm{RO}_{2}+\mathrm{NO}+\mathrm{M}=\mathrm{RONO}_{2}+\mathrm{M} \quad \text { (alkylnitrate) }
$$

Table 1 PAN levels (ppbv) determined in this study and relative comparison with other studies

\begin{tabular}{lccc}
\hline PAN level & Average value & Range & Reference \\
\hline Rome (this work) & 2.1 (winter) & $0.1-7.3$ & \\
& 5.7 (summer) & $0.1-30.3$ & \\
Antartica & 9.3 & $0.8-33.2$ & {$[1]$} \\
Mexico City & 15.0 & $0.1-34$ & {$[6]$} \\
Santiago & 2.4 & $0.1-7.6$ & {$[3]$} \\
\hline
\end{tabular}

$$
\begin{aligned}
& \mathrm{RO}_{2} \cdot+\mathrm{NO}_{2}+\mathrm{M}=\mathrm{RO}_{2} \mathrm{NO}_{2}+\mathrm{M} \quad \text { (peroxyalkylnitrate) } \\
& \mathrm{RO}_{2} \cdot+\mathrm{HO}_{2} \cdot=\mathrm{ROOH}+\mathrm{O}_{2} \quad \text { (idroperoxy) }
\end{aligned}
$$

In these condition the ozone formation kinetic is also influenced by other factors such as VOC species, the relative reaction coefficients for producing $\mathrm{RO}_{2}$ and $\mathrm{OH}$ radicals. It is well-known that nitrous acid $\left(\mathrm{HNO}_{2}\right)$ and formaldehyde $(\mathrm{HCHO})$ play a fundamental role in processes occurring in atmosphere [24,25]. In Figures 4-6 the trends of PAN, ozone, formaldehyde and $\mathrm{O}_{\mathrm{x}}$ determined in downtown Rome, are reported.

First of all, looking at Figure 4 high correlation between PAN and ozone is found (Pearson's coefficient of correlation 0.84) meaning a strict relationship between them. These considerations can be evident especially during stable atmospheric conditions (investigated using the natural radioactivity, radon) when the pollutant dispersion is not favored (from $7^{\text {th }}$ to $18^{\text {th }}$ ) whereas during the remaining periods a low correlation is observed which depends on the chemical reactions occurring in atmosphere.

Considering all the reactions above reported, Figure 5 shows that high $\mathrm{HCHO}$ concentrations are present in the late morning and afternoon whereas minimum 


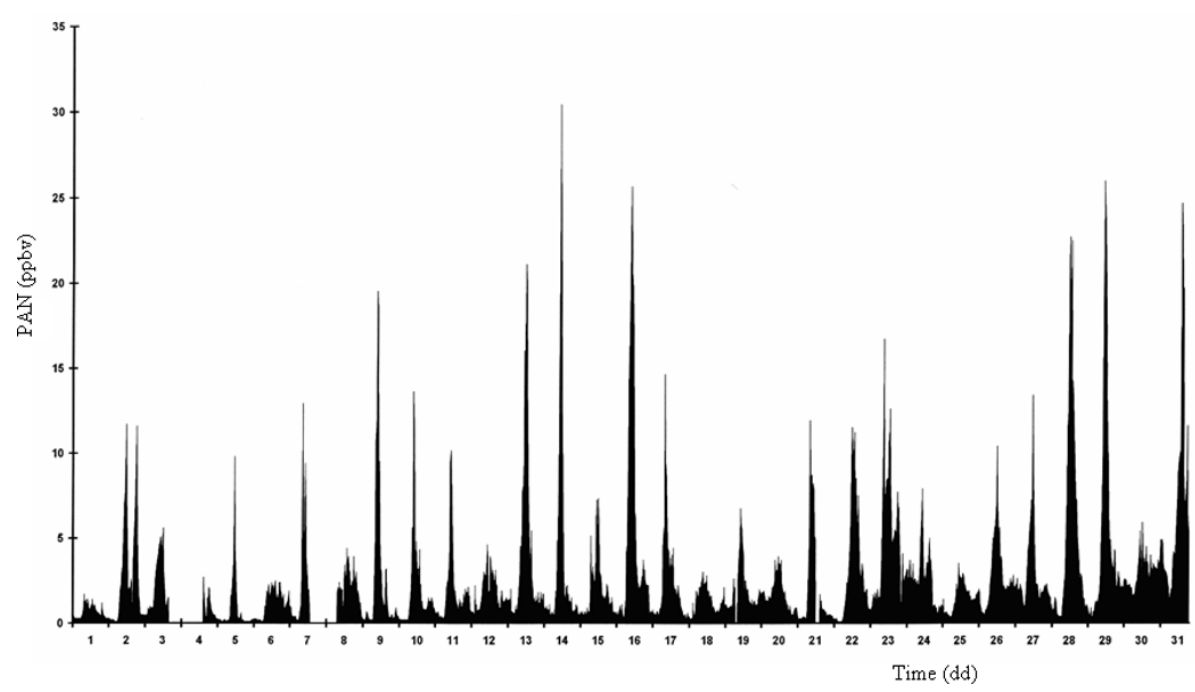

Figure 2 Typical daily trend of PAN during a summer period (Rome, Villa Ada).

values are found during high solar radiation hours: in particular, the higher levels are determined in the hour range 13.00-15.00 when the highest ozone concentrations are detected.

As it can be seen in Figure 6, the pollutant behaviors are interesting. In fact, the kinetics between PAN and $\mathrm{HCHO}$ are different: in atmosphere, the $\mathrm{HCHO}$ formation reaction is more rapid than the relative PAN formation whereas the PAN removal is very quickly. This means that during regular atmospheric mixing conditions (unstable conditions) no pollutant accumulation is possible: on the contrary, during stable conditions (i.e., when pollutant dispersion is not favored) smog photochemical episodes can occur. The intensity of such phenomena depends on variables above described: in any case the result of the event is very high $\mathrm{PAN}$ and $\mathrm{HCHO}$ levels and consequently maximum ozone concentrations.

This different behavior is well-reported in Figure 6. The $\mathrm{O}_{\mathrm{x}}$ variable is the sum of $\mathrm{O}_{3}$ and $\mathrm{NO}_{2}$ and describes the atmospheric radical conditions: when no reactions occur, the daily trend of the $\mathrm{O}_{\mathrm{x}}$ variable is constant because $\mathrm{O}_{3}$ and $\mathrm{NO}_{2}$ have a symmetrical behavior strictly depending on the solar radiation, i.e. high ozone levels in the early morning with $\mathrm{NO}_{2}$ removal and opposite trend in the rest of the morning. During smog photochemical episodes higher levels of $\mathrm{HCHO}$ (Figure 7) and PAN are found: simultaneously, the various reactions cause an ozone accumulation and the relative sum of ozone and

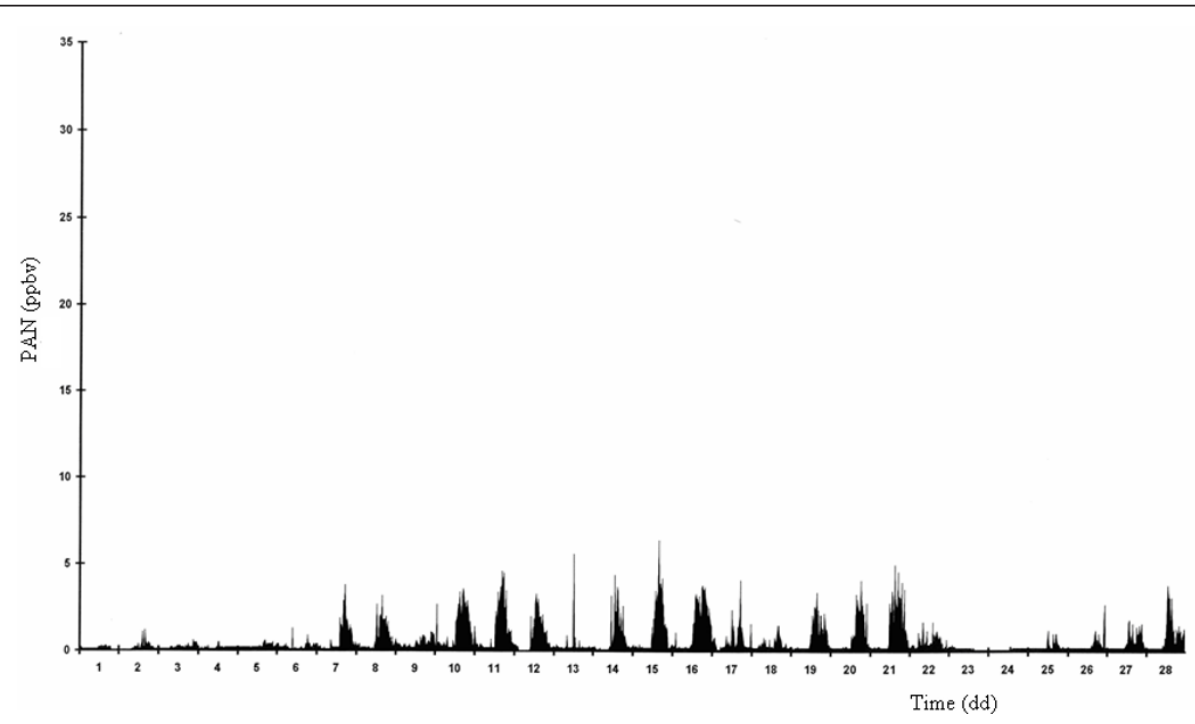

Figure 3 Typical daily trend of PAN during a winter period (Rome, Villa Ada). 
Table 2 Average and max concentration levels (ppbv) and relative contribution (\%) of each $\mathrm{C}_{2}-\mathrm{C}_{9}$ hydrocarbons measured in atmosphere of downtown Rome

\begin{tabular}{|c|c|c|c|}
\hline$C_{2}-C_{9}$ & Average & Max & $\%$ \\
\hline Ethane & 8.3 & 18.7 & 10.5 \\
\hline Ethene & 20.4 & 126.0 & 25.7 \\
\hline Propane & 6.0 & 25.6 & 7.6 \\
\hline Propene & 3.3 & 14.4 & 4.2 \\
\hline n-Butane & 4.1 & 32.0 & 1.3 \\
\hline i-Butane & 1.1 & 27.8 & 5.2 \\
\hline 1-Butene & 1.1 & 10.1 & 1.3 \\
\hline cis-2-Butene & 2.7 & 8.4 & 3.3 \\
\hline trans-2-Butene & 0.2 & 4.3 & 0.3 \\
\hline n-Pentane & 7.4 & 40.0 & 9.3 \\
\hline i-Pentane & 2.0 & 84.9 & 2.5 \\
\hline cis-2-Pentene & 0.5 & 5.5 & 0.6 \\
\hline trans-2-Pentene & 0.7 & 5.5 & 0.9 \\
\hline 2-Methylpentane & 1.1 & 21.5 & 1.4 \\
\hline 3-Methylpentane & 3.6 & 22.2 & 4.5 \\
\hline Isoprene & 0.2 & 1.6 & 0.2 \\
\hline n-Hexane & 0.3 & 7.9 & 0.3 \\
\hline Cyclohexane & 0.4 & 12.9 & 0.5 \\
\hline Benzene & 3.5 & 3.0 & 1.3 \\
\hline n-Heptane & 0.8 & 3.5 & 1.0 \\
\hline Toluene & 5.9 & 20.4 & 7.9 \\
\hline Ethylbenzene & 1.2 & 14.0 & 1.5 \\
\hline m- \& p-Xylenes & 3.9 & 16.5 & 5.0 \\
\hline o-Xylene & 0.6 & 5.1 & 0.8 \\
\hline Styrene & 1.2 & 6.1 & 1.5 \\
\hline 1,2,4-Trimethylbenzene & 0.6 & 3.4 & 0.8 \\
\hline 1,3,5-Trimethylbenzene & 0.5 & 3.5 & 0.6 \\
\hline$\overline{\text { Total } C_{2}-C_{9}}$ & 81.6 & 544.8 & 100.0 \\
\hline
\end{tabular}
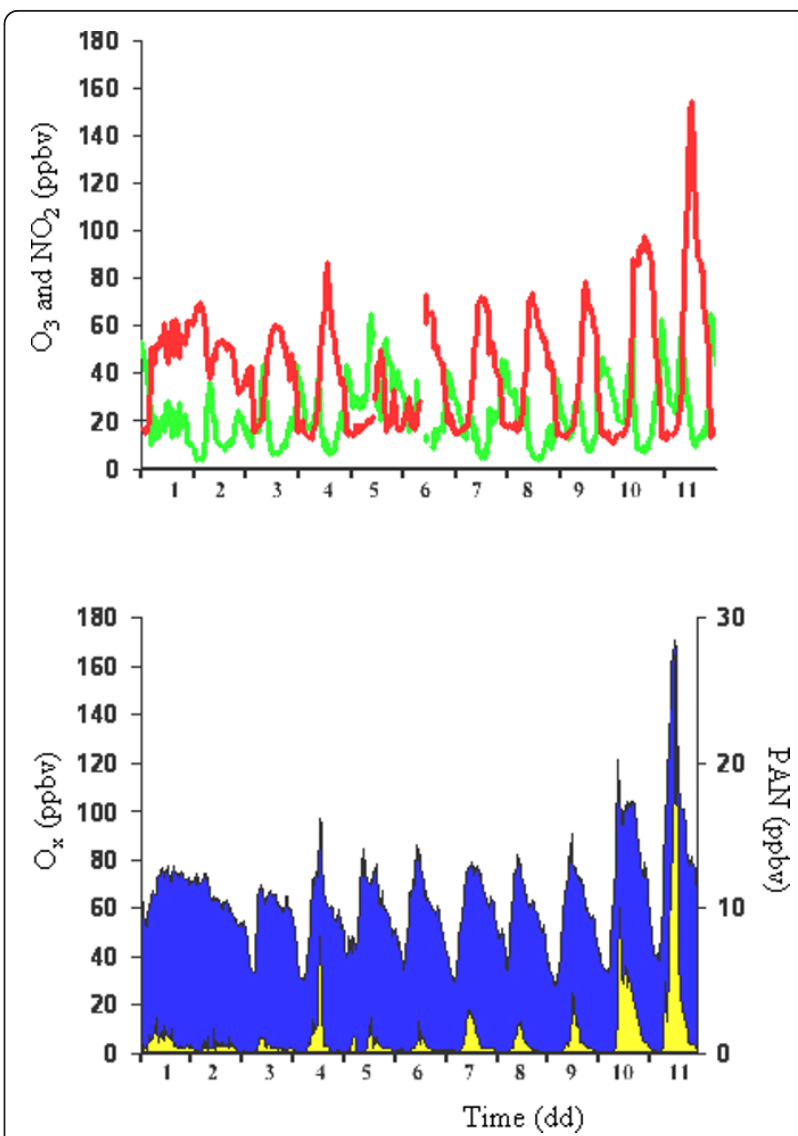

Figure 6 Typical daily trends of $\mathrm{NO}_{2}$ (green), $\mathrm{O}_{3}$ (red), $\mathrm{O}_{x}$ (blue) and PAN (orange) during a summer period.

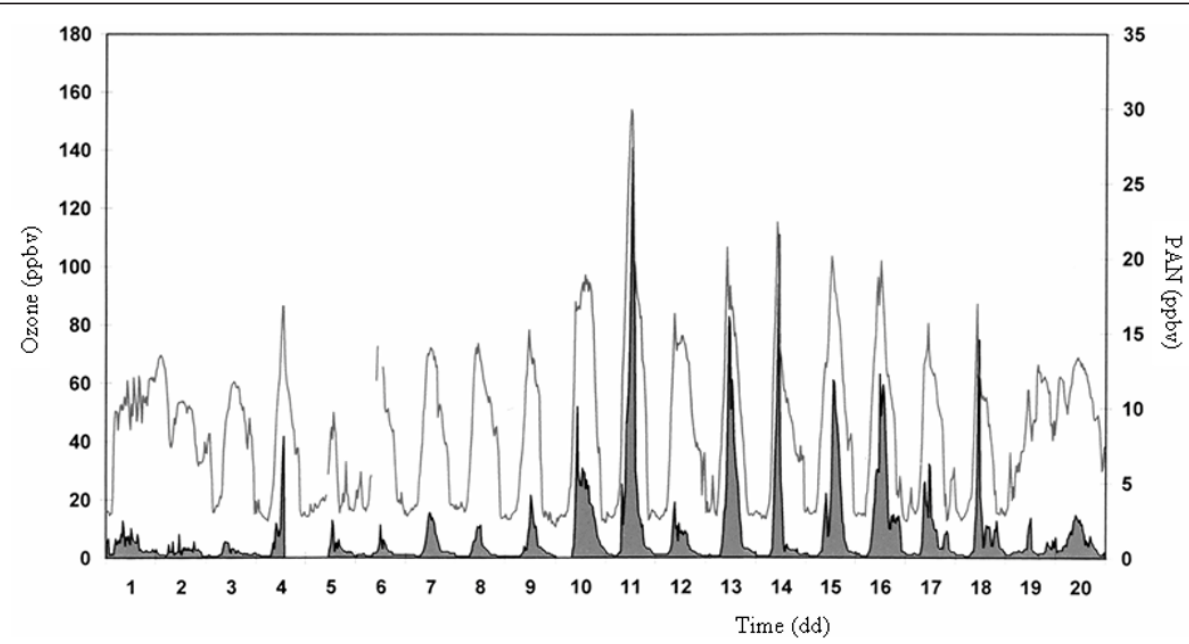

Figure 4 Typical daily trends of PAN (area) and ozone (line) during a summer period. 


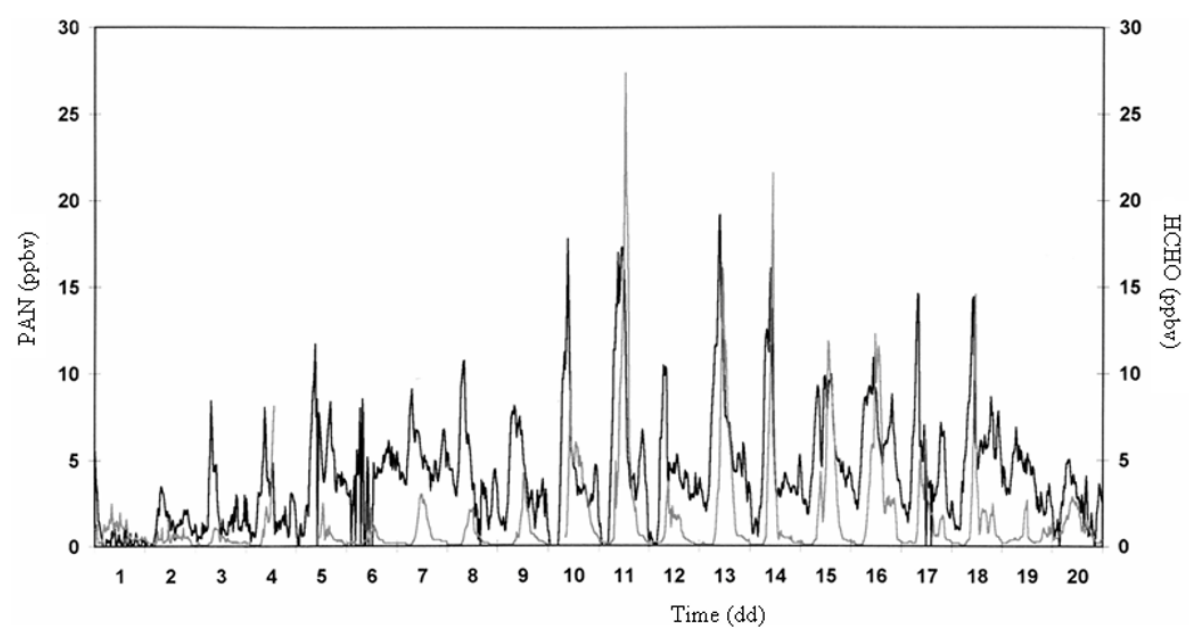

Figure 5 Typical daily trends of PAN (grey line) and $\mathrm{HCHO}$ (bold line) during a summer period.

$\mathrm{NO}_{2}$ is not constant during the day. The behaviors of $\mathrm{O}_{\mathrm{x}}$ and $\mathrm{HNO}_{2}$ can be considered an evidence of the occurrence of a smog photochemical episode (Figure 7).

In order to foresee photochemical pollution prevention, it is important to evaluate the relation between ozone and its precursors (VOCs and $\mathrm{NO}_{\mathrm{x}}$ ). This evaluation has been always performed by mathematical models. In this approach we have considered the daily ratios of $\mathrm{VOCs} / \mathrm{NO}_{\mathrm{x}}$ determined in downtown Rome: they range between 1.3 and 5.5. About the VOC reactivity, from Table 2 it is possible to evidence that the olefin fraction is prevalent in the VOC composition (about $40 \%$ ) and consequently plays an important and interesting role in the atmospheric chemical and photochemical reactions [26] with the aromatic fraction (about $15 \%$ of the total VOCs).

\section{Experimental}

Measurements of PAN were carried out by means of a gas-chromatography (Carlo Erba Instruments, Milan, Italy). An electron capture detector (ECD) equipped with a ${ }^{63} \mathrm{Ni}$-foil of $10 \mu \mathrm{Ci}$ was used a glass tube (length $30 \mathrm{~cm}$, i.d. $2 \mathrm{~mm}$ ) packed with $10 \%$ Carbonwax on Chromosorb 80/100 mesh served with a column. Carrier-gas was nitrogen (purity of 99.99\%). The flow-rate

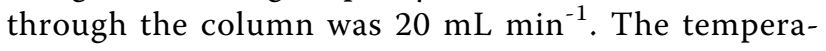
ture of the GC oven was kept at $35^{\circ} \mathrm{C}$, whereas the detector's temperature was $100^{\circ} \mathrm{C}$. An external pump (flow-rate $800 \mathrm{~mL} \mathrm{~min}^{-1}$ ) supplied the GC with ambient air, and every $15 \mathrm{~min}$ air samples (sampling volume of $2 \mathrm{~mL}$ ) were automatically injected into the GC system through a 4-port valve regulated by pressurized air: the PAN retention time is 2.35 min whereas the detection limit is $0.001 \mathrm{ppb}$. Data were recorded by a Shimadzu integrator.
To prepare small amount of PAN a mixture of 50 ppm isobutene and $5 \mathrm{ppm} \mathrm{NO}_{2}$ diluted in synthetic air was undergone to irradiation by vapor $\mathrm{Hg}$ lamp [27].

Ozone and $\mathrm{NO}_{2}$ have been measured by means of a Differential Optical Absorption Spectrometry (DOAS, Opsis, Sweden) based on the Lambert-Beer's law [28]. For describing the dynamics of the low boundary layer meaning the atmospheric stability/instability conditions was used the natural radioactivity by means of the $\beta$ radioactivity of short-lived decay products of Radon (SM200, Opsis) [29].

VOC concentrations have been measured by means of gas chromatograph POCP GC955 (Syntech Spectras, The Netherlands) equipped with two columns and three detectors. For the $\mathrm{C}_{2}-\mathrm{C}_{5}$ hydrocarbons an alumina column $(15 \mathrm{~m} \times 0.32 \mathrm{~mm}, 0.10 \mu \mathrm{m}$ film thickness) (Alltech Ass. Inc., Illinois, USA) and two detectors flame ionization (FID) and photo ionization (PID) were used whereas for the $\mathrm{C}_{6}-\mathrm{C}_{10}$ hydrocarbons a column AT5 (15 $\mathrm{m} \times 0.32 \mathrm{~mm}, 0.10 \mu \mathrm{m}$ film thickness) (Alltech Ass. Inc.) and a photo-ionization detector (PID).

The sampling site was located in downtown Rome (37 $\mathrm{m}$ a.s.l.; $41^{\circ} 54^{\prime} \mathrm{N}$ and $12^{\circ} 30^{\prime} \mathrm{E} ; 2.7$ million inhabitants), site characterized by high density of autovehicular traffic due to 2.5 millions among cars, motorcycles and bus (data from Automobile Club d'Italia) and domestic heating. The measurements covered 12-months from May 2007 to April 2008.

\section{Conclusions}

The daily trends of ozone and PAN are reported and discussed together with the $\mathrm{NO}_{2}$ and $\mathrm{HCHO}$ behaviors in relationship with the concentrations of the natural radioactivity (radon) used as parameter for describing the dynamic of low atmospheric boundary layer. PAN 

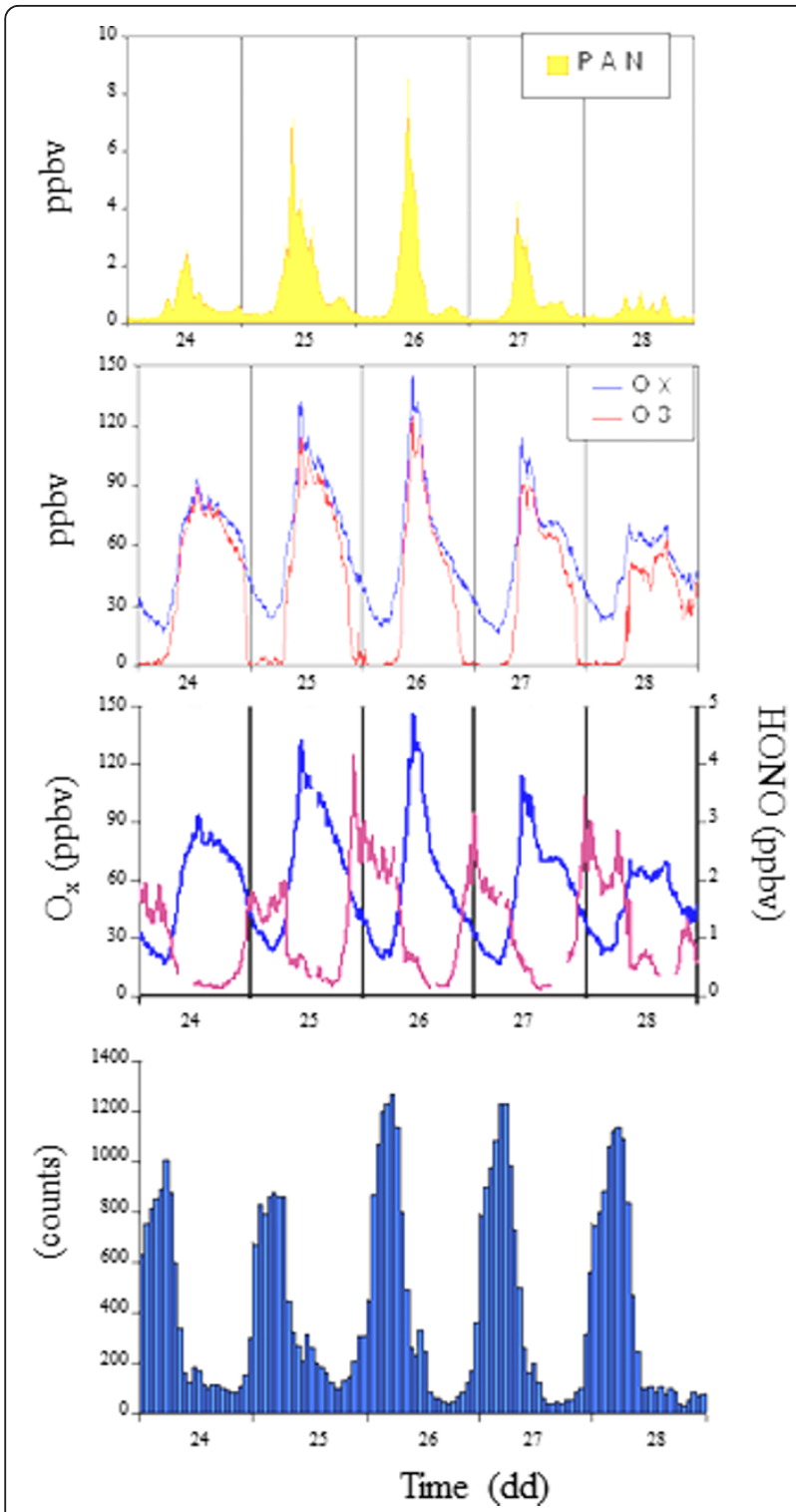

Figure 7 a) Typical trends of $\mathrm{PAN}, \mathrm{O}_{x}$ and $\mathrm{O}_{3}$ during a summer period (June, $24^{\text {th }}-28^{\text {th }}$ ) in relationship with the radon concentration behavior; b) trends of $\mathrm{HNO}_{2}$ and $\mathrm{O}_{x}$ during photochemical activity in summer period.

has a low chemical reactivity and it represents a selective index of photochemical activity in atmosphere also because it is almost negligible the natural sources on its budget. Furthermore, PAN measurements are also important for investigating photochemical pollution transport phenomena.

For identifying the acute episodes of atmospheric photochemical pollution the PAN trends are shown and compared with those of the variable $\mathrm{O}_{\mathrm{x}}$ (sum of $\mathrm{NO}_{2}$ and $\mathrm{O}_{3}$ ) describing specifically the evolution and the fate of oxidative processes due to atmospheric radical activity. At the same time, a VOC profile is reported and it is shown that the main contribution to the ozone formation comes from the olefinic fraction representing almost $40 \%$ of the total VOC amount. For this reason it is still an important issue to control the autovehicular emissions and to reduce and/or minimize the $\mathrm{NO}_{\mathrm{x}}$ fractions in fuel.

Finally, as important part of the project, an analytical methodology based on GC-ECD analysis without sample enrichment and with high reliability and accuracy, was developed.

\section{Acknowledgements}

This work was supported under the grant ISPESL/DIPIA/P06 "Identificazione, analisi e valutazione delle conseguenze delle attività antropiche (Identification, analysis and evaluation of consequences of anthropogenic activities)" L06, 2008-11. Further, the authors wish to thank drs. D. Brocco and A. Febo for their helpful contribution in the discussion.

This article has been published as part of Chemistry Central Journal Volume 6 Supplement 2, 2012: Proceedings of CMA4CH 2010: Application of

Multivariate Analysis and Chemometry to Cultural Heritage and Environment. The full contents of the supplement are available online at http://journal. chemistrycentral.com/supplements/6/S2.

\section{Author details}

'Department of Chemistry, University of Isfahan, Isfahan, 81744, Iran. ${ }^{2}$ Facoltà di Agraria, Università del Molise, via De Sanctis, Campobasso, Italy. ${ }^{3}$ DIPIAISPESL, via Urbana 167, Rome, 00184, Italy.

\section{Authors' contributions}

PA and MV set up the analytical procedure using GC-ECD. KM processed data and provided the comparison with other literature. PA and MV coordinated the study. PA edited the text and prepared the final draft of the paper. All the authors have read and approved the final manuscript.

\section{Competing interests}

The authors declare that they have no competing interests.

Published: 2 May 2012

\section{References}

1. Mills GP, Sturges WT, Salmon RA, Bauguitte SJ-B, Read KA, Bandy BJ: Seasonal variation of peroxyacetylnitrate (PAN) in coastal Antarctica measured with a new instrument for the detection of sub-part per trillion mixing ratios of PAN. Atmos Chem Phys 2007, 7:4589-4599.

2. Taylor OC: Importance of peroxyacetylnitrate (PAN) as a phytotoxic air pollutant. J Air Pollut Control Assoc 1969, 19(5):347-351.

3. Rubio MA, Gramsch E, Lissi E, Villana G: Seasonal dependence of peroxyacetylnitrate (PAN) concentrations in downtown Santiago, Chile. Atmosfera 2007, 20(4):319-328.

4. World Health Organization (WHO): Update and Revision of the WHO Air Quality Guideline for Europe. Classical Air Pollutants; Ozone and Other Photochemical Oxidants. Bilthoven, Netherlands; 1996.

5. Gaffney JS, Marley NA, Cunningham MM, Doskey PV: Measurements of peroxyacyl nitrates (PANs) in Mexico City: implications for megacity air quality impacts on regional scales. Atmos Environ 1999, 33(30):5003-5012.

6. Marley NA, Gaffney JS, Ramos-Villegas R, Cárdenas González B: Comparison of measurements of peroxyacyl nitrates and primary carbonaceous aerosol concentrations in Mexico City determined in 1997 and 2003. Atmos Chem Phys 2007, 7:2277-2285.

7. Dyremark A, Westerholm R, Överik E, Gustavsson J-A: Polycyclic aromatic hydrocarbon (PAH) emissions from charcoal grilling. Atmos Environ 1995, 29(13):1553-1558.

8. Brown JR, Field RA, Goldstone ME, Lester JN, Perry R: Polycyclic aromatic hydrocarbons in central London air during 1991 and 1992. Sci Total Environ 1996, 177(1-3):73-84.

9. Kawanaka Y, Matsumoto E, Sakamoto K, Wang N, Yun S-J: Size distributions of mutagenic compounds and mutagenicity in atmospheric particulate 
matter collected with a low-pressure cascade impactor. Atmos Environ 2004, 38(14):2125-2132.

10. Bravo HA, Camacho CR, Roy-Ocotla RG, Sosa ER, Torres RJ: Analysis of the change in atmospheric urban formaldehyde and photochemistry activity as a result of using methyl-t-butyl-ether (MTBE) as an additive in gasolines of the metropolitan area of Mexico City. Atmos Environ 1991, 25(2):285-288.

11. Streit GE, Guzman F: Mexico City air quality: progress of an international collaborative project to define air quality management options. Atmos Environ 1996, 30(5):723-733.

12. Avino $P$, Manigrasso M: Ten-year measurements of gaseous pollutants in urban air by an open-path analyzer. Atmos Environ 2008, 42(18):4138-4148.

13. Bridier I, Caralp F, Loirat H, Lesclaux R, Veyret B, Becker KH, Reimer A, Zabel F: Kinetic and theoretical studies of the reactions acetylperoxy + nitrogen dioxide $+M$.dblarw. acetyl peroxynitrate $+M$ between 248 and $393 \mathrm{~K}$ and between 30 and 760 torr. J Phys Chem 1991, 95:3594-3600.

14. Kley D, Kleinmann M, Sanderman H, Krupa S: Photochemical oxidants: state of the science. Environ Pollut 1999, 100(1):19-42.

15. Nielsen T, Samuelsson U, Grennfelt C, Thomsen EL: Peroxyactyl nitrate in long range transported pollution air. Nature 1981, 293:553-555.

16. Ridley BA, Shetter JD, Walega JG, Madronich S, Elsworth CM, Grahek FE, Fehsenfeld FC, Norton RB, Parrish DD, Huebler G, Buhr M, Williams EJ, Allwine EJ, Westberg HH: The behavior of some organic nitrates at Boulder and Niwot Ridge, Colorado. J Geophys Res 1990, 95(D9):13949-13961.

17. Aneja VP, Harstsell BE, Kim D-S, Grosjean D: Peroxyacetyl nitrate in Atlanta, Georgia: comparison and analysis of ambient data for suburban and downtown locations. J Air Waste Manag Assoc 1999, 49(2):177-184.

18. En-Jang S, Ming-Huei H: Detection of peroxyacetyl nitrate at phytotoxic level and its effects on vegetation in Taiwan. Atmos Environ 1995, 29(21):2899-2904.

19. Bottenheim JW, Gallant AJ: PAN over the Arctic, observations during AGASP-2 in April 1986. J Atmos Chem 1989, 9(1-3):301-316.

20. Rappengluck B, Melas D, Fabian P: The evolution of photochemical smog in the metropolitan area of Santiago, Chile. J Appl Meteorol 2000, 39(3):275-290.

21. Rappengluck B, Oyola P, Olaeta I, Fabian P: Evidence of the impact of urban plumes on remote sites in the Eastern Mediterranean. Atmos Environ 2003, 37(13):1853-1864.

22. Morris WE, Dishart KT: Influence of vehicle emission control systems on the relationship between gasoline and vehicle exhaust hydrocarbon composition. Effect of Automotive Emission Requirements on Gasoline Characteristics. ASTM Special Publication 487 Philadelphia, PA, USA: American Society for Testing and Materials;13-9780803100046 1977, 69-101.

23. Mayrsohn H, Crabtree JH, Kuramoto M, Sothern RD, Mano SH: Source reconciliation of atmospheric hydrocarbons 1974. Atmos Environ 1977, 11(2):189-192.

24. Crutzen PJ, Fishman J: Average concentrations of $\mathrm{OH}$ in the troposphere, and the budgets of $\mathrm{CH}_{4}, \mathrm{CO}, \mathrm{H}_{2}$ and $\mathrm{CH}_{3} \mathrm{CCl}_{3}$. Geophys Res Lett 1977, 4(8):321-324.

25. Baulch DL, Cox RA, Crutzen PJ, Hampson RF, Kerr JA, Troe J, Watson RT: Evaluated kinetic and photochemical data for atmospheric chemistry. Supplement I J Phys Chem Ref Data 1982, 11(2):327-496.

26. Field RA, Goldstone ME, Lester JN, Perry R: The sources and behavior of anthropogenic volatile hydrocarbons. Atmos Environ 1992 26(16):2983-2996.

27. Schurath U, Wipprecht V: Reactions of peroxiacyl radicals. In Proceedings of the 1st European Symposium on the Physico-Chemical Behavior of Atmospheric Pollutants, Concerted Action EEC-COST 61A bis. Commission European Community; Versino B 1980:157-166.

28. Avino P, Brocco D, Lepore L, Russo MV, Ventrone I: Remote sensing measurements for evaluation of air quality in an urban area. Ann Chim 2004, 94(9-10):707-714.

29. Avino P, Brocco D, Lepore L, Pareti S: Interpretation of atmospheric pollution phenomena in relationship with the vertical atmospheric remixing by means of natural radioactivity measurements (radon) of particulate matter. Ann Chim 2003, 93(5-6):589-594.
doi:10.1186/1752-153X-6-S2-S8

Cite this article as: Movassaghi et al:: The determination and role of peroxyacetil nitrate in photochemical processes in atmosphere.

Chemistry Central Journal 2012 6(Suppl 2):S8.

\section{Publish with ChemistryCentral and every scientist can read your work free of charge \\ "Open access provides opportunities to our colleagues in other parts of the globe, by allowing anyone to view the content free of charge." \\ W. Jeffery Hurst, The Hershey Company. \\ - available free of charge to the entire scientific community \\ - peer reviewed and published immediately upon acceptance \\ - cited in PubMed and archived on PubMed Central \\ - yours - you keep the copyright \\ Submit your manuscript here: \\ http://www.chemistrycentral.com/manuscript/<smiles>c1ccccc1</smiles> \\ ChemistryCentral}

